\begin{abstract}
"Mircea cel Batran" Naval Academy Scientific Bulletin, Volume XIX - 2016 - Issue 1
Published by "Mircea cel Batran" Naval Academy Press, Constanta, Romania // The journal is indexed in: PROQUEST / DOAJ / DRJI / JOURNAL INDEX / I2OR / SCIENCE LIBRARY INDEX / Google Scholar / Crossref /

Academic Keys / ROAD Open Access / OAJI / Academic Resources / Scientific Indexing Services / SCIPIO
\end{abstract}

\title{
THE SEA IN OLD ENGLISH LITERATURE
}

\author{
Isabela MERILA ${ }^{1}$ \\ ${ }^{1}$ Senior Lecturer, PhD English Department, Faculty of Letters, "Dunarea de Jos" University of Galati
}

\begin{abstract}
The sea has been a constant presence in English literature: from Shakespeare to Coleridge and to Conrad, authors have included representations of this complex body of water in a variety of works covering the majority of genres. This should not come as a surprise to any reader, considering England's geographical position and the way this influenced its history and its cultural makeup in general. Following the tradition of archetypal criticism, we chose to trace the representations of the sea back to their origins and focus on the earliest remaining texts from Old English Literature in search of prevalent symbolic values, as well as their connection to Anglo-Saxon ethos.
\end{abstract}

\section{Keywords: sea, archetype, Old English}

Sharing in Northrop Frye's perspective on the archetype as "a typical or recurring image [...] a symbol which connects one poem with another and thereby helps to unify and integrate our literary experience" (1957: 99), we aim to trace the various occurrences of the sea archetype in some of the Anglo-Saxon poems that remain to us and detect in what way their symbolic value adds to the whole of the text.

Considering the geographic coordinates of the places the authors of the poems inhabited, we already have a level of expectation as to the general aspect of these seas. As George Sanders stated in connection to early English literature:

The sea of our forefathers was not a gracious Mediterranean washing with blue water the steps of marble palaces, but an ocean grey and tumultuous beating upon dismal shores and sterile promontories. The very land seems as cruel as the sea. No song of lark or nightingale gladdens life for these shore-dwellers; their loneliness is made more terrible by the scream of sea birds crying about the cliffs or by strange sounds that mingle with the moan of the wind across the meres (1999: 1).

Of the few songs that remain from the AngloSaxons, in written form and collected in manuscripts, we selected those that seem most relevant to the theme of this research, namely The Seafarer, The Wanderer and Beowulf (all titles given in the $19^{\text {th }} \mathrm{c}$.). The selection also allows for a movement between genres, since the first two are classified as lyric poems, while Beowulf is an epic, therefore, the focus is placed on narrative. All three poems have probable dates of composition sometime between the $8^{\text {th }}$ and the $10^{\text {th }}$ century and the poets who created them are unknown. Since the current research is more interested in the way Old English literature translates to the contemporary public (rather than the specialist in Anglo-Saxon dialects), the examples present throughout this text were chosen from three of the best renderings into modern English to date, belonging to Michael Alexander, Charles W. Kennedy and Seamus Heaney, respectively.

We cannot discuss the symbolic values of the sea without referring to the primordial element that it represents and its complexity. Water generates representations ranging from the extreme positive to the extreme negative and from the material to the spiritual. It can be both masculine, under the form of rain, for example, and, more often than not, feminine. Probably one of the first to spring to mind is its connection with life and fertility, whether in the sense of the rain needed for agriculture or maternal waters.

However, just as any maternal representation can be positive and nurturing, as well as overwhelming and consuming, this symbolic value of water becomes associated with death if in excess. Incessant rains become floods, thus turning blessing into punishment. The latter also reveals another connection with the idea of purification. And if the example of the flood is extreme, even apocalyptic, the more frequent cases seem to be those similar to baptism. Moreover, both may also be connected with rebirth. From the immersion into the depths for cleansing and receiving, perhaps, a (new) name, to visiting underwater realms and coming back changed, if at all, the experience can stand for a challenge, a stage of the quest, a step towards initiation.

In most cases the return is impossible: the individual is no longer the same, or the realm he used to inhabit is no longer his home. It is the case of Oisín from Celtic tradition, who is taken to Tir na nOg, the Land of Youth, by Niamh, the daughter of Manannán Mac Lir, the god of the ocean. Tradition locates this land across the western waves, or its entrance is said to be beneath the waters of a lake. While Oisín lives a blessed life there, he becomes homesick and 


\begin{abstract}
"Mircea cel Batran" Naval Academy Scientific Bulletin, Volume XIX - 2016 - Issue 1
Published by "Mircea cel Batran" Naval Academy Press, Constanta, Romania // The journal is indexed in: PROQUEST / DOAJ / DRJI / JOURNAL INDEX / I2OR / SCIENCE LIBRARY INDEX / Google Scholar / Crossref /

Academic Keys / ROAD Open Access / OAJI / Academic Resources / Scientific Indexing Services / SCIPIO
\end{abstract}

desires to return. Niamh warns him against it and, finally, gives him an enchanted horse and tells him that under no circumstance should he touch earth: the actual return to the previous state or world is impossible.

A similar impossibility marks the fountain: it is more often than not a connection with a world of superior, even metaphysical knowledge and accessing it requires a sacrifice. Odin offers one of his eyes in exchange for the chance to drink from the well of wisdom, and, thus, he gains sight into the unseen. In other words, it is one more example of water being connected to spiritual life, which is not surprising if we consider with Chevalier and Gheerbrant (1994) that rain is seen as a connection between up and down, while, as mentioned above, still waters can be a connection and a separation between this life and the next, or this realm and a hidden one.

Alternatively, water can be a highly psychological symbol: its depths can stand for the unconscious, with its mysteries, traps and revelations; rivers have often been associated with life paths or with the connection between the underground and the surface, literally and figuratively; still waters have the power to act as mirrors, revealing and distorting, and when they are transparent, they are similar to windows, etc.

Hence, even when referring to a specific embodiment of this symbol, namely the sea, the representations promise to be quite varied and complex. Seas figure prominently in many cosmogonic myths of the world, if it is only to mention the Babylonian and the Japanese. They are both connections between distant lands and barriers. We can think, for example, of the way certain stories express extreme distances: over seven lands and seven seas. They are often correlated with the idea of sacrifice, whether meant to appease them or as part of their very nature. For instance, in the Germanic cosmogony, the seas are created from the blood of the giant Ymir.

The depths stand for mystery, danger and initiation, as well as infinite possibilities, which correlate them once more with the human psyche, while for the Christians, the sea is often the world, with the church as the ship.

The latter reference was considered particularly significant by certain interpreters of Anglo-Saxon literature, especially in the case of poems such as The Seafarer and, to a certain extent, The Wanderer, as they present an interesting mixture of Christian elements with those belonging to Germanic mythology and ethos. Whether this is due to the fact that they were older songs transcribed by monks who intervened in the text to adapt it to contemporary taste and circumstances, or because they were composed by Anglo-Saxon monks themselves, the debate considered both possibilities and seems to incline towards the latter (Donoghue 2004; Fulk and Cain 2005). What might be more relevant for this research is the effect this mixture has on the whole of the text. The Seafarer, for one, is written from the perspective of one solitary speaker who seems to wander the seas of his own volition. He declares, in the first lines, that he tells of his own experience: "The tale I frame shall be found to tally:/ the history is of myself" (Anon. 2008b: 1-2). As soon as this dramatic monologue begins, we are sailing: "Sitting day-long/ at an oar's end clenched against clinging sorrow,/ breast-drought I have borne, and bitternesses too" (2-4). The mention of the oar is too general to point to an exact body of water, as yet. However, the mention of the "breast-drought" establishes a connection between the spirit and the primordial element, while the word "drought" provides the latter with a positive connotation by comparison.

Therefore, the somewhat negative description that follows seems at first, contradictory: "over furled foam, I forward in the bows/ through the narrowing night, numb, watching/ for the cliffs we beat along. Cold then/ nailed my feet, frost shrank on/ its chill clamps, cares sighed/ hot about heart, hunger fed/ on a mere-wearied mind. No man blessed/ with a happy land-life is like to guess/ how I, achinghearted, on ice-cold seas/ have wasted whole winters; the wanderer's beat,/ cut off from kind" (616). The description of the sea as ice-cold is both direct and through the reaction of the sailor, who is numb with frost and pinned down as in a torture session. Moreover, the sequence "cares sighed hot about the heart" results in an antithesis built on the contrast between the temperature of the body and that of the spirit, while, at the same time, revealing the fact that the spirit is equally tormented.

The other antithesis is between the hard and tiring life on sea and the happy life on land, which helps to create a sense of loneliness, in spite of one mention of "we". All of the other references are to an "I", which makes this a highly personal experience and one which seems to belong to his past, if we are to consider the time reference to "then" in line 8.

In his own tale, he is a wanderer away from his people, just as in the "eponymous" poem mentioned above, and his solitary destiny is further developed in the following lines. There, the only sound he is said to hear is the "slam of waves along an icy sea" (18) and he continues to draw a parallel between what could be expected from the life of a land-dweller and the realities of the sailor: instead of the laughter of men, he hears 


\section{"Mircea cel Batran" Naval Academy Scientific Bulletin, Volume XIX - 2016 - Issue 1 \\ Published by "Mircea cel Batran" Naval Academy Press, Constanta, Romania /I The journal is indexed in: PROQUEST / DOAJ / DRJI / JOURNAL INDEX / I2OR / SCIENCE LIBRARY INDEX / Google Scholar / Crossref / \\ Academic Keys / ROAD Open Access / OAJI / Academic Resources / Scientific Indexing Services / SCIPIO}

the call of the curlew; instead of feasts in the hall, with drinking of mead, he listens to the sound of gulls; instead of entertainment, he has the blare of the swan.

The entire sequence seems to focus obsessively on sound: "To the storm striking the stone cliffs/ gull would answer, eagle scream/ from throats frost-feathered" (23-25). On the background of night, this is even more effective in transmitting the feeling of loneliness, which is finally expressed directly in lines 25-26: "No friend or brother/ by to speak with the despairing mind". Furthermore, the most frequent symbolic value of birds seems to be that of connectors between the skies and earth, between the divine and the human, being frequently associated with spirituality. Therefore, this might be another clue as to the archetypal value of the sea in the poem.

The next lines connect the journey on waters with exile while developing the contrast with the life of men on land: "This he little believes whose life was run/ sweet in the burgs, no banished man,I but well seen at wine-round, my weariness of mind/ on the ways stretching over the salt plains" (27-30). And, as night thickens, snow comes from the north to cover the frozen earth.

Despite the dismaying picture painted above, starting with line 33 there seems to be a return to the speaker's present and the revelation of his longing for a return to the sea: "I am to cross again./ Mind-lust maddens, moves as I breathe/ soul to set out, seek out the way/ to a far folk-land flood-beyond" (35-38). This is particularly surprising since the experience is said to elicit fear in the heart of whoever considers it. However, the call of the sea is so strong that no earthly joy can take his mind off it: "His heart is not in harping nor in the having of rings, / has no delight in women nor the world's gladnesses/ nor can think of any thing outside the thrash of waves,/ sea-struck, is distracted, stillness lost" (44-47). Summer itself with all its joys seems to have no other effect than urge "the eagerly mooded man to venture on the voyage [...] the faring over flood" (51-52). The song of the cuckoo bird, instead of filling him with joy for the coming of warmer times, instead "calls him in his care-laden voice" (53).

The speaker's singularly directed reactions start to become more understandable as he muses on the transitoriness of life, starting with line 67. There are two particularly Germanic elements in this section: Fate and fame.

Fate, or wyrd, is, in Germanic tradition, the sense of change to which everything is subject. Accordingly, it encompasses the sum total of one's individual actions and choices, as well as whatever destiny may have been predetermined by the Nornir for that individual. [...] Its pattern and flow is the one constant immutable law governing every aspect of existence" (Krasskova 2005: 121). Even the gods are subject to its power. The poet of The Seafarer finds a place for this old belief under the Christian wing in the homiletic ending sequence: "Doom is stronger and God is mightier than any man's conception". Under these circumstances, the only thing a worthy man can do is make a name for himself by means of his deeds, a theme particularly reinforced in the poem Beowulf. Thus, in The Seafarer, for the "doom shadowed" earl, it is "the praise of livers-on, that, lasting, is best" (74).

Nevertheless, the poet also constructs another antithesis, between past and present, this time: "there are no gold-givers like the gone masters/ who between them framed the first deeds in the world/ in their lives lordly, in the leys renowned./ That chivalry is changed, cheer is gone away,/ it is a weaker kind who wields earth now,l sweats for its bread" (83-88). The heroic age is over and feudalism is taking its place. Thus, we return to the vanitas theme, and the source of the seafarer's longing becomes even clearer. In facing the seas, true man has one last chance of daring. Cosy life on land is not for him, as it is clearly expressed by his regret for a more worthy past and by the realization that everything there is fleeting. Material wealth is useless, he states, since no amount of gold is going to appease the anger of God towards a sinful soul (98-103). This perspective reinforces the reading suggested by the expression used in the beginning of the poem, "breast-drought", and repeated in line 62, "the breast hungry and thirsty", framing sailing as a spiritual activity, and the sea, with its variety of birds, as the closest to the metaphysical. This also sheds new light on the isolation of the speaker: forced earthly exile can be seen as a reference to the fact that life and death are deeply individual experiences and that man takes nothing with him, except good deeds, as in the medieval drama Everyman.

This sense of loneliness is even stronger in the poem The Wanderer, which, in spite of its references to the Christian God's compassionate love and pity in the beginning and the end, it is closer to the pre-Christian tradition throughout. Just as in the case of The Seafarer, the first setting is the sea: "Though woefully toiling on wintry seas/ With churning oar in the icy wave,I Homeless and helpless he fled from Fate" (Anon. 1973: 3-5). Already there are several elements that are common with the previous poem: the cold seas, the mention of Fate, exile and, thus, solitude. However, this time, the dramatic monologue of the Wanderer is introduced by a narrator/ commentator, which helps with the 


\begin{abstract}
"Mircea cel Batran" Naval Academy Scientific Bulletin, Volume XIX - 2016 - Issue 1
Published by "Mircea cel Batran" Naval Academy Press, Constanta, Romania // The journal is indexed in: PROQUEST / DOAJ / DRJI / JOURNAL INDEX / I2OR / SCIENCE LIBRARY INDEX / Google Scholar / Crossref /

Academic Keys / ROAD Open Access / OAJI / Academic Resources / Scientific Indexing Services / SCIPIO
\end{abstract}

passage from personal experience to generalized perspective. The number of words pointing at the wanderer's state of mind is overwhelming: wretchedness, woe, misery, sorrow, hapless, grief, some of them repeated under various derivations several times in the text. However, the clear indication is that it is a reflection of his inner torment, not public display, as that would be unacceptable according to Anglo-Saxon ethos.

Another common point with The Seafarer is the contrast between past and present. The story of the wanderer seems to be that of an old retainer who lost his comrades and his lord. He is the last man standing, hence his exile, his loneliness. The past comes into his dreams and memories, and the setting of the mead hall comes back to life with its feasts, companionship, ring giving and loyalty pledges. Hence, when the dream dissipates and we are presented with the cold, stormy and lonely setting of the sea, the antithesis is quite striking: "dreaming he claspeth his dear lord again,/ Head on knee, hand on knee, loyally laying,/ Pledging his liege as in days long past./ Then from his slumber he starts lonely-hearted,/ Beholding gray stretches of tossing sea,/ Seabirds bathing, with wings outspread,/ While hailstorms darken, and driving snow" (36-42).

In this context, the birds no longer seem to be a connection between heaven and earth as in The Seafarer, but rather one more device to emphasize the wanderer's solitude and, perhaps, even a reminder of death. This would bring them closer to the symbolism of the so-called "beasts of battle" that are usually present in heroic poems such as The Battle of Maldon, but which receive a special mention here as well, namely in lines 7475. Their presence is part of the above-referenced movement from the personal to the universal. It is not only the speaker's life that changed from a happy past into a desolate present, but the whole of the earth as well.

On the background of a panoramic description of ruins and death, the ubi sunt motif deplores the end of the heroic age: "Where now is the warrior? Where is the warhorse?/ Bestowal of treasure and sharing of feast?/ Alas! the bright ale cup, the byrny-clad warrior,/ The prince in his splendor those days are long sped/ In the night of the past, as if they never had been" (84-88). That the wanderer is one of the last exponents of that heroic past is supported by the gnomic statements attributed to him in lines 12-17, 58-65, which contain some of the guidelines of Anglo-Saxon ethos. But the other warriors seem to have perished in a great battle of such apocalyptic proportions that it almost reminds one of Ragnarok, the Twilight of the Gods, the final clash when even the gods will perish.
The all-powerful Wyrd dominates the scene here as well - "fate's decrees transform the world" (99) - and it is combined with the vanitas theme: "Here wealth is fleeting, friends are fleeting,/ Man is fleeting, maid is fleeting;/ All the foundation of earth shall fail" (100-102). Under such circumstances, there is no future in sight, no hope to speak of and the earth seems abandoned, empty. And since it was previously connected to the life the wanderer had in his youth, the sea, instead, can be perceived as an escape from that, as an attempt to lose those memories that cause him pain: "Then again surges his sorrow upon him;/ And grimly he spurs his weary soul/ Once more to the toil of the tossing sea" (49-51).

And while in The Seafarer there was a feeling that, despite the harshness of life on seas, on a certain level, it is the only life that fulfils a purpose for the speaker, that takes him on a spiritual journey, the wanderer is said to try and flee from Fate (line 5) so as to lose his troubled heart amidst all the tossing of the sea, which he knows to be equally futile. Despite the Christian sentiments of the first two lines of the poem and the last six, the other lines do not give any hope of passing into the Lord's keeping, striving for a better spiritual life.

Furthermore, there is another connection occasioned by the references to winter. The first one is to the wintry seas: "woefully toiling on wintry seas" (3), "and I sailed away with sorrowful heart,I Over wintry seas" (22-23); then, as a means of counting years of experience: "No man may know wisdom till many a winter/ Has been his portion" (58-59). Finally, there is the apocalyptic description of cold engulfing the earth: "Storms now batter these ramparts of stone;/ Blowing snow and the blast of winter/ Enfold the earth; night shadows fall/ Darkly lowering, from the north driving/ Ranging hail in wrath upon men" (93-97). Besides creating a specific distant-north type of setting, which, once more, connects the poem with the Germanic tradition, it also creates the feeling that, if the earth is approaching its end, so is the sea and so is the wanderer. In true warrior fashion, however, he will keep on going till the end.

This entire perspective may remind the reader of Deor, where the upstaged and exiled eponymous poet provides examples from history and myth of other people who faced strife and hardships and concludes each story with: "that went by; this may too" (Anon. 2008a: 71-72). However, it is quite clear that the end is not going to be finding another master, for example, but the natural end that comes to all things.

This stoic attitude is common to all Anglo-Saxon verse that remains, be it lyric or heroic. It is one of 


\section{"Mircea cel Batran" Naval Academy Scientific Bulletin, Volume XIX - 2016 - Issue 1 \\ Published by "Mircea cel Batran" Naval Academy Press, Constanta, Romania /I The journal is indexed in: PROQUEST / DOAJ / DRJI / JOURNAL INDEX / I2OR / SCIENCE LIBRARY INDEX / Google Scholar / Crossref / \\ Academic Keys / ROAD Open Access / OAJI / Academic Resources / Scientific Indexing Services / SCIPIO}

the main differences David Daiches (1991: 49) identifies between Old English verse and the medieval romances. While in the latter, the outcome of a battle often depends on the moral uprighteousness, the Germanic warrior of the poems knows that no matter how loyally he follows his code of honour, Fate might still lead him on a terrible path. Still, with this knowledge, he still follows the code, because this is what a wise, brave man will do if he is "eager for honour" (Anon. 1973: 16).

And no one in the Anglo-Saxon tradition is more famous for following the way of the warrior than Beowulf. He summarizes its guidelines when he tries to console king Hrothgar on the loss of his most trusted advisor: "Wise sir, do not grieve. It is always better/ to avenge dear ones than to indulge in mourning./ For every one of us, living in this world/ means waiting for our end. Let whoever can/ win glory before death. When a warrior is gone,/ that will be his best and only bulwark" (Anon. 2000: 1383-1389).

Since he is the hero of an epic, the fact that he has superior strength and prowess comes as no surprise. The definition of the genre provides extra information about what one can expect: "a long narrative poem, on a grand scale, about the deeds of warriors and heroes. It [usually incorporates] myth, legend, folk tale and history" (Cuddon 1998: 264). Therefore, it may be safe to say that the primordial elements will play an important role in the delineation of the story.

Accordingly, in the case of Beowulf, water is a complex part of the world the characters inhabit. The setting is sparsely delineated as being in the north and between two seas. Shield Sheafson, the leader of the Spear-Danes whose story opens the poem, manages to subdue the tribes "on the outlying coasts/ beyond the whale-road" (Anon. 2000: 9-10) and make them pay tribute. It is one of the several reasons the poet brings to support his evaluation of Shield: "That was one good king" (11) and this king is brought to the Danes by the sea, since he is an orphan found in a boat. His departure follows the same path, as he receives a sea funeral worthy of his deeds: he is set on a ship with war equipment and piles of riches and they launch "him alone out over the waves" (46). It is a northern rite that underlines the transcending symbolic value of water: the apparent infinity of the ocean, the line of the horizon where it seems to meet the skies, etc., they all connect it with ideas of ascension, spirituality and continuity.

Beowulf himself comes from beyond the sea to help the Danes in their hour of need. The latter call him and his companions: sea-rovers, seafarers, Sea-Geats etc. In such contexts, the symbolism of the water is clearly positive.
The depths, however, tell a slightly different tale. Beowulf is famed for a swimming contest that turned into battle. In his own words, as part of a challenge, he and Breca swam shoulder to shoulder for five nights and none could leave the other behind. But then "the long flow/ and pitch of the waves, the perishing cold,/ night falling and winds from the north/ drove us apart. The deep boiled up/ and its wallowing sent the sea-brutes wild" (545-550). One of the ocean creatures attacks the hero and he is forced to fight for his life. He manages to kill all "sea beasts", "foul things", "monsters", so the waves settle and the light of God rises to mark his victory over darkness, while he concludes: "From now on/ sailors would be safe, the deep-sea raids/ were over for good" (567-569). In other words, like many of the most remarkable epic protagonists, Beowulf is firstly a protector of humanity and one who rids the world of ungodly creatures. This is what motivates his most remarkable deeds of bravery in the poem.

This episode is recalled as an introduction in the hall of Shield's descendant, Hrothgar, a worthy king set not only on fighting, but on building as well. The construction of Heorot, his hall, is described in the beginning of the poem in parallel with the Biblical tale of Genesis and its impressiveness is stressed several times. It is the noise of the banquet at the completion of the hall that enrages Grendel and drives him to start attacking the humans.

Genealogies are quite important in the AngloSaxon tradition, and they are used to shed light on the character of a particular person. And just as in the case of Beowulf and Hrothgar, the reader is presented with Grendel's origins as well: “Grendel was the name of this grim demon/ haunting the marches, marauding round the heath/ and the desolate fens; he had dwelt for a time/ in misery among the banished monsters,I Cain's clan, whom the Creator had outlawed/ and condemned as outcasts. [...] out of the curse of his exile there sprang/ ogres and elves and evil phantoms/ and the giants too who strove with God/ time and again until He gave them their reward" (102-114). His mother is a demon who lives in a cave under a lake; therefore, she is a creature of the underground, not yet developed enough on the scale of mythical evolution to inhabit the surface. Grendel, on the other hand, seems a hybrid of two primordial elements. He lives in water soaked places, at the border between his mother's world and that of the humans. This might be the reason why he receives a name and a certain amount of pity from the poet, whereas she does not.

Beowulf's past history with water demons, already announces him as an initiate, as someone who 


\begin{abstract}
"Mircea cel Batran" Naval Academy Scientific Bulletin, Volume XIX - 2016 - Issue 1
Published by "Mircea cel Batran" Naval Academy Press, Constanta, Romania /I The journal is indexed in: PROQUEST / DOAJ / DRJI / JOURNAL INDEX / I2OR / SCIENCE LIBRARY INDEX / Google Scholar / Crossref /

Academic Keys / ROAD Open Access / OAJI / Academic Resources / Scientific Indexing Services / SCIPIO
\end{abstract}

could defeat the two foes, when ordinary humans stand no chance. Since Grendel is closer to being human, the hero defeats him in hand-to-hand combat. To defeat his mother, however, Beowulf needs a special sword that he finds in her cave and which melts afterwards, a sign that it may not be used by another man or for another battle. Furthermore, the hero's katabasis and anabasis show that he has to leave the mortal world to fight her, which raises him even higher on the scale of initiatic accomplishments.

When his work is done, he returns to his ship and heads back home victoriously in a beautiful description of the act of sailing: "Then the keel plunged/ and shook in the sea; and they sailed from Denmark./ Right away the mast was rigged with its sea-shawl;/ sail-ropes were tightened, timbers drummed/ and stiff winds kept the wavecrosser/ skimming ahead; as she heaved forward,/ her foamy neck was fleet and buoyant,/ a lapped prow loping over currents,/ until finally the Geats caught sight of coastline/ and familiar cliffs. The keel reared up,/ wind lifted it home, it hit on the land" (1903-1913).

Therefore, we may say that the sea has an essential role in Anglo-Saxon tradition - a mark of their common northern inheritance as well as of their newly established insularity. Out of the three chosen literary examples, The Seafarer showed how the Christian perspectives are combined with the sense of the earth being ruled by wyrd, which established the sea as a spiritual path to follow, in spite of the hardships, cold and solitude it entails. The petty cares of an earthly life are lost at sea. Furthermore, embracing this type of life is somewhat presented as one last brave deed left in the world that the old sailor can perform, thus, in keeping with what being a true man means for the Anglo-Saxons.

The Wanderer keeps this sense of sea sought as sanctuary, though an equally wintry one, from the desolation of an earth emptied of life and rimecovered. However, there is no uplifting, spiritual sense of heading towards a better life purpose. Instead, the stormy sea seems to act rather as a mirror of the wanderer's tormented memory and for the sense of loss that follows him everywhere.

Finally, Beowulf creates the most complex representation, with the sea covering all coordinates. First of all, it connects people and surrounds their known world. Secondly, it is a mysterious path on which great heroes are sent to their eternal rest as part of their rite of passing, a name that always presupposes another realm, a better one in this case, often imagined on a vertical, upward axis. On the same axis, but downward, it is the world of the monsters that haunt the waters and threaten the peace of the earth-dwellers. Therefore, the water connects and separates at the same time, it is the source of positive and negative representations, it is part of the initiatic journey and its hidden meanings are only available to those brave enough to venture on or in it, while also possessing the wisdom and the honourable, true heart required for the journey.

All these aspects combine into a nuanced and powerful archetype that is represented as aweinspiring throughout.

\title{
BIBLIOGRAPHY
}

[1] Anon. (2000) Beowulf. transl. by Heaney, S. London: Faber and Faber

[2] Anon. (2008a) Deor. transl. by Alexander, M. in First Poems in English. London: Penguin Books, 71-72

[3] Anon. (2008b) The Seafarer. transl. by Alexander, M. in First Poems in English. London: Penguin Books, 55-58

[4] Anon. (1973) The Wanderer. transl. by Kennedy, C.W. in The Oxford Anthology of English Literature. ed. by Kermode, F. and Hollander, J. vol. 1. New York: O.U.P., 101-104

[5] Chevalier, J. and Gheerbrant, A. (1994) "Apa". transl. by Irina Bojin. in Dictionar de simboluri. Bucuresti: Artemis, 107-117

[6] Cuddon, J.A. (1998) Dictionary of Literary Terms and Literary Theory. London: Penguin Books

[7] Daiches, D. (1991) A Critical History of English Literature. London: Seer and Warburg

[8] Donoghue, D. (2004) Old English Literature. Malden: Blackwell Publishing

[9] Frye, N. (1957) Anatomy of Criticism. Princeton: P.U.P.

[10] Fulk, R.D. and Cain, C.M. (2005) A History of Old English Literature. Malden: Blackwell Publishing

[11] Krasskova, G. (2005) Exploring the Northern Tradition. Franklin Lakes: New Page Books

[12] Sampson, G. (1999) The Concise History of English Literature. $3^{\text {rd }}$ edn. Cambridge: C.U.P. 